\title{
AREAS OF PUBLIC ORGANIZATIONS' INFLUENCE ON LEGAL CULTURE AS A BASIS FOR CIVIL SOCIETY FORMATION: THEORETICAL AND LEGAL PREMISES
}

\section{Larysa Udovyka}

\section{INTRODUCTION}

The experience of social development of modern democratic countries clearly shows that the level of civilizational development in general and that of political, legal and cultural development in particular, depend significantly on the functioning of civil society. Civil society as a socially organized structure, which is formed outside political structures but coordinated with the political organization of society, encourages settlement of public conflicts by legal means, "enables attraction of additional human, organizational, financial and technical resources in order to provide social and other socially significant services, promote decentralization of public administration and its quality improvement, reduce public expenditure and prevent corruption risks" 1 .

Amongnumerous subjects of civil society, an essential role is played by public organizations, which, among other things, influence the formation of citizens' legal culture and encourage them to take an active public and legal stand. In recent years, public organizations have initiated a number of activities aimed at reforming the judiciary, fighting corruption, establishing democracy and protecting human rights. In all public areas and at all levels, state and local, the role of public organizations has increased significantly. Their activities are aimed at reforms in public areas and e-government development, rise in transparency and accountability of public authorities to the Ukrainian society, promotion of European integration, provision of volunteer assistance to the Armed Forces of Ukraine and law enforcement agencies in the anti-terrorist operation, support of internally displaced persons. Therefore, the study of the theoretical and legal premises for the areas of public organizations' influence on legal culture as a basis of civil society formation is a crucial practical problem that requires a thorough comprehensive study.

It is also necessary to take into account the fact that globalization and integration processes, in which Ukraine is involved, intensify and deepen the

\footnotetext{
${ }^{1}$ National Strategy for the Support of Civil Society Development in Ukraine for 2016-2020 (2016). Approved by the President of Ukraine Decree No. 68/2016 of February 26, 2016 "On Support of Civil Society Development in Ukraine", [Online], available at: https://zakon.rada.gov.ua/laws/show/68/2016\#n20.
} 
interaction of national and global civil society. The complexity and prospects for the civil society development in Ukraine largely depend on the values and priorities, based on which the society will be developing, the degree of the European legal, political, and cultural values significance for Ukraine as well as on the fact which of these values will be promoted in the Ukrainian society. It is also important to expand the areas of cooperation between civil society organizations and Member States of the European Union.

Given the above-stated, the purpose of the present paper is to study the theoretical and legal premises for the areas of public organizations' influence on legal culture as a basis for civil society formation.

Research methods. To achieve this goal, we used an integrated set of philosophical, general scientific and special scientific approaches, methods and means of cognition in our research. The civilizational approach aims to determine the relationship between civil society and the state, clarify the role of legal culture in the formation and development of civil society. According to the fundamental laws of dialectics, the areas of public organizations' influence on the improvement of legal culture, their theoretical and legal premises caused by the contradictions between the real level of legal culture and the desirable, practical one are characterized by a certain correlation of quantitative and qualitative indicators. Among the general scientific methods of cognition, we used an axiological method (in the study of the principles and values of civil society, current legislation norms); a system structural method (in the research of the theoretical and legal premises for the areas of public organizations' influence, civil society structure, legal culture structure, their relationship); a functional method (for understanding the content of public organisations' activities, revealing the process of legal culture improvement, civil society functioning); a statistical method (for describing the quantitative indicators of public organizations' functioning). Special scientific methods used in our research involve a formal dogmatic method (for analysing the current legislation on regulation of public associations' activities, premises for civil society functioning in Ukraine), legal determinism (when grounding the areas of public associations' influence on legal culture, relationship between the level of legal culture and civil society development), and others.

Degree of the problem scientific development. Over the recent decade, the study of the role of public organizations in the development of civil society has aroused great interest among Ukrainian and foreign researchers. Special attention should be paid to the writings of the following foreign scholars: J. Habermas, P. Herrmann, G. Domanski, J.-L. Laville, D. Lewis, W. Powell, R. Putnam, T. Parsons, P. Play, D. Stone, A. Tocqueville, S. Feldman, J. Fischer, J.R. Hay, P. Schmitter, etc. Among the numerous works devoted to the study of civil society in general and public organizations in particular, we 
should highlight the achievements of Ukrainian scientists, namely O. Vashchuk, L. Voitova, A. Ivchenko, V. Kovalenko, A. Kolodii, A. Liasota, A. Matviichuk, V. Polokhalo, L. Usachenko, V. Stepanenko, M. Shevchenko, O. Yuldashev.The works addressingthe legal aspects of activities and relations of public organizations and public authorities are of special significance as well, namely the papers by U. Volynets, M. Vikhliaiev, V. Dementov, A. Halai, V. Kovalchuk, V. Kravchuk, S. Ponomarov, I. Stronianska, I. Tkachuk. However, we should take into account the enhancement of the content and nature of public associations' activities, transformation of the dynamics of civil society functioning in Ukraine, changes in the legal regulation of public associations' activities, complexity of their activities, which requires constant attention to this issue. The analysis of the scientific literature has shown that the theoretical and legal premises for the areas of public organizations' influence on legal culture as a basis of the civil society formation remain unexplored in legal science and should be subject to a thorough consideration.

\section{Legal premises for activities of public organizations as subjects of civil society}

The analysis of scientific sources shows that in modern social and humanitarian science there is no single, generally accepted understanding of the concept of civil society. One group of scientists interprets it as a set of interactions between individuals that have developed in the course of activity for protection of human rights and freedoms. The second group mainly includes institutionalized forms of such interactions in civil society, primarily public associations that have been established and registered in accordance with the current legislation. At the same time, they share a common point that creation of public organizations by citizens is the best possible way to exercise rights and freedoms as well as to satisfy various interests. Public associations are major subjects of civil society, given their goals, tasks and legal status.

The importance of public associations is recognized at international and national levels and enshrined in a number of international, European and national legal acts. The right to freedom of association is reaffirmed by other major international treaties on human rights, including the International Covenant on Civil and Political Rights ${ }^{2}$, the Convention for the Protection of

\footnotetext{
${ }^{2}$ UN General Assembly. International Covenant on Civil and Political Rights (December 16, 1966), United Nations. Treaty Series, vol. 999, p. 171, Article 22, [Online], available at: https://www.ohchr.org/en/professionalinterest/pages/ccpr.aspx
} 
Human Rights and Fundamental Freedoms ${ }^{3}$, the International Covenant on Economic, Social and Cultural Rights ${ }^{4}$, the American Convention on Human Rights, the Charter of Fundamental Rights of the European Union ${ }^{5}$, etc.

The right to freedom of association has been repeatedly confirmed by judicial practice at international and national levels. In addition, over the past few decades, a number of international governmental and non-governmental organizations have drafted and adopted many documents that proclaim the right to freedom of association. These documents include, inter alia, recommendations, resolutions, interpretative decisions of treaty bodies and reports of UN Special Rapporteurs. They laid the foundation for "soft" law and content of the Guidelines on Freedom of Association, which interpret the term "association" as "... an organized, independent, not-for-profit body based on the voluntary grouping of persons with a common interest, activity or purpose. An association does not have to have legal personality, but does need some institutional form or structure" 6 .

Among a wide range of problems, which public associations deal with, a significant part is related to the level of legal culture, namely human rights (combating discrimination), assistance in activities of national human rights institutions, protection of the rights of children, women, migrants, refugees, prevention and overcoming of violence in all forms, implementation of democratic reforms, provision of legal protection, socio-economic issues, humanitarian assistance, etc.

Thus, at the international level, there is a strong legal framework that regulates the right to freedom of association and lays the grounds for national law and legislation to recognize the right to association of individuals as an integral part of civil society. The Constitution of Ukraine and a number of laws are important in understanding the legal premises for the activities of public associations, which constitute, among other things, the premises for influencing legal culture as the basis for the civil society formation in Ukraine.

${ }^{3}$ Council of Europe. European Convention for the Protection of Human Rights and Fundamental Freedoms, as amended by Protocols Nos. 11 and 14, 4 November 1950, Article 11, [Online], available at: http://conventions.coe.int/treaty/Commun/QueVoulezVous.asp? NT $=005 \& C L=E N G$.

${ }^{4}$ UN General Assembly. International Covenant on Economic, Social and Cultural Rights (December 16, 1966), United Nations, Treaty Series, vol. 993, p. 3, Article 8.Retrieved from:https://www.ohchr.org/Documents/ProfessionalInterest/cescr.pdf

${ }^{5}$ European Union. Charter of Fundamental Rights of the European Union (October 26, 2012), 2012/C 326/02, Official Journal of the European Union, Article 12, [Online], available at: https://eur-lex.europa.eu/legal-

content/EN/TXT/?uri=uriserv:OJ.C_.2012.326.01.0391.01.ENG\&toc=OJ:C:2012:326:TOC

${ }^{6}$ The OSCE Office for Democratic Institutions and Human Rights (2015) Guidelines on Freedom of Association, p. 15. Retrieved from: https://www.osce.org/odihr/132371? download=true 
Thus, according to Article 36 of the Constitution of Ukraine, "Citizens of Ukraine have the right to freedom of association in political parties and public organizations for the exercise and protection of their rights and freedoms and for the satisfaction of their political, economic, social, cultural and other interests, with the exception of restrictions established by law in the interests of national security and public order, the protection of the health of the population or the protection of rights and freedoms of other persons" Article 37 of the Constitution of Ukraine provides for restrictions concerning the establishment and activities of political parties and public associations, which are prohibited"...if their programme goals or actions are aimed at the liquidation of the independence of Ukraine, the change of the constitutional order by violent means, the violation of the sovereignty and territorial indivisibility of the State, the undermining of its security, the unlawful seizure of state power, the propaganda of war and of violence, the incitement of interethnic, racial or religious enmity, and the encroachments on human rights and freedoms, and the health of the population. Political parties and public associations shall not have paramilitary formations" $"$.

There are some other Articles of the Constitution, which are fundamental for the legal regulation of public associations. They provide for the right to freedom of thought and speech, free expression of views and beliefs (Article 34), the right to file individual or collective petitions, or to personally appeal to bodies of state power, bodies of local self-government, and to the officials and officers of these bodies that are obliged to consider the petitions and to provide a substantiated reply within the term established by law (Article 40), the right to openness of a trial and its complete recording by technical means (Article 129), etc. ${ }^{9}$

7 The ConstitutionofUkraine(June 28, 1996), Vidomosti Verkhovnoi Rady Ukrainy [The Official Bulletin of the Verkhovna Rada of Ukraine], 1996, No 30, Art. 141 (asamended by the Law of Ukraine "On A mendments to the Constitution of Ukraine (concerning justice)" (June 2, 2016), Vidomosti Verkhovnoi Rady Ukrainy [The Official Bulletin of the Verkhovna Rada of Ukraine], 2016, No 51, p. 8, Art. 1799), [Online], available at: https://zakon.rada.gov.ua/ laws/main/254\%D0\%BA/96-\%D0\%B2\%D1\%80

${ }^{8}$ The Constitution of Ukraine (June 28, 1996), Vidomosti Verkhovnoi Rady Ukrainy [The Official Bulletin of the Verkhovna Rada of Ukraine], 1996, No 30, Art. 141 (asamended by the Law of Ukraine "On A mendments to the Constitution of Ukraine (concerning justice)" (June 2, 2016), Vidomosti Verkhovnoi Rady Ukrainy [The Official Bulletin of the Verkhovna Rada of Ukraine], 2016, No 51, p. 8, Art. 1799), [Online], available at: https://zakon.rada.gov.ua/laws/ main/254\%D0\%BA/96-\%D0\%B2\%D1\%80

${ }^{9}$ The Constitution of Ukraine (June 28, 1996), Vidomosti Verkhovnoi Rady Ukrainy [The Official Bulletin of the Verkhovna Rada of Ukraine], 1996, No 30, Art. 141 (asamended by the Law of Ukraine "On A mendments to the Constitution of Ukraine (concerning justice)" (June 2, 2016), Vidomosti Verkhovnoi Rady Ukrainy [The Official Bulletin of the Verkhovna Rada of Ukraine], 2016, No 51, p. 8, Art. 1799), [Online], available at: https://zakon.rada.gov.ua/laws/ main/254\%D0\%BA/96-\%D0\%B2\%D1\%80 
The concept and division of public associations is enshrined in Ukrainian legislation. Thus, in accordance withArticle 1 of the Law of Ukraine "On Public Associations", "A public association is a voluntary association of physical persons and/or legal entities under private law for the purpose of exercising and protecting rights and freedoms, and satisfying public, among them economic, social, cultural, environmental, and other interests. As far as its organizational and legal form is concerned, a public association is established as a public organization or a public union. A public organization is a public association the founders and members (participants) of which are physical persons. A public union is a public association, the founders of which are legal entities under private law and whose members (participants) may be legal entities under private law and/or physical persons" $" 10$.

The influence of public associations on the formation of legal culture as a basis for building civil society in Ukraine is primarily determined by the legal premises for their activities. Therefore, it is necessary to define in general terms the legal premises for public associations' activities in Ukraine. Thus, according to the Law of Ukraine "On Public Associations", Article 21 "The Rights of Public Associations", to implement its purpose (goals), a public association shall have the right to, in particular: "2) address bodies of state power, the bodies of power of the Autonomous Republic of Crimea, and local self-government bodies, their officers and employees with proposals (criticism), requests (petitions), and complaints in accordance with established procedure; 3) obtain, in accordance with established procedure, public information at the disposal of the authorities and other public information holders..."11 Thus, public associations have a fairly wide range of rights so that to achieve their goals and objectives, namely: to apply to public authorities in general, and the judiciary in particular, to obtain the necessary information. At the legislative level, there is the Regulation that public associations can jointly realize their goals and may engage in cooperation with foreign non-governmental organizations and international governmental organizations in compliance with the laws of Ukraine (Article 6 of the Law of Ukraine "On Public Associations")"

${ }^{10}$ The Law of Ukraine (Mar. 22, 2012) No. 4572-VI "On Public Associations", Vidomosti Verkhovnoi Rady Ukrainy [The Official Bulletin of the Verkhovna Rada of Ukraine], 2013, No 1, Art. 1, [Online], available at: https://zakon.rada.gov.ua/laws/show/4572-17

${ }^{11}$ The Law of Ukraine (Mar. 22, 2012) No. 4572-VI "On Public Associations", Vidomosti Verkhovnoi Rady Ukrainy [The Official Bulletin of the Verkhovna Rada of Ukraine], 2013, No 1, Art. 1, [Online], available at: https://zakon.rada.gov.ua/laws/show/4572-17(in Ukrainian) (accessed 03 January 2020).

12 The Law of Ukraine (Mar. 22, 2012) No. 4572-VI "On Public Associations", Vidomosti Verkhovnoi Rady Ukrainy [The Official Bulletin of the Verkhovna Rada of Ukraine], 2013, No 1, 
Summarizing various scientific views on public associations and given the fundamental principles of their organization, activities and peculiar features, a public association can be defined as voluntary, self-governing, independent, transparent, public, non-profit association of citizens, which is established to protect the rights and freedoms, based on common interests of its members and aimed at achieving socially significant goals, namely economic, legal, social, cultural, environmental, etc. Public organizations is represented by various professional unions, women's, youth, veterans', children's organizations, scientific, technical, cultural, educational, sports and other voluntary associations of citizens, creative unions, organizations, foundations, etc. The most significant role in affecting the state legal policy, functioning of public authorities, the judiciary in particular, is played by human rights public organizations, whose main goal is to protect the rights and freedoms of human and citizen, to efficiently supervise their observance and protection by the state, its bodies and officials.

In the context of the legal framework for public organizations' activities and their role in shaping legal culture, the Laws "On Access to Public Information"13, "On Access to Court Decisions"14, "On the Judiciary and the Status of Judges"15 are of great importance as well. Article 3 of the Law of Ukraine "On Access to Public Information" 16 provides for the guarantees of observance of the right to access to public information, namely: transparency and openness of the activities of government agencies; free receipt, distribution and any other use of information that was provided or made public in accordance with this Law, except for restrictions established by the law; equality, regardless of the race, political, religious and other beliefs, gender, ethnic and social origin, property status, place of residence, language or other characteristics.

In addition to the above laws, the legal premises for public associations' activities, which determine the areas of their influence on legal culture, are enshrined in other laws regulating certain types of public associations, such as

Art. 1, [Online], available at: https://zakon.rada.gov.ua/laws/show/4572-17(in Ukrainian) (accessed 03 January 2020).

${ }^{13}$ The Law of Ukraine (Jan. 13, 2011) No. 2939-V "On Access to Public Information", Vidomosti Verkhovnoi Rady Ukrainy [The Official Bulletin of the Verkhovna Rada of Ukraine], 2011, No 32, Art. 314, [Online], available at: https://zakon.rada.gov.ua/laws/show/2939-17.

${ }^{14}$ The Law of Ukraine (Dec. 22, 2005) No. 3262-IV "On Access to Court Decisions", Vidomosti Verkhovnoi Rady Ukrainy [The Official Bulletin of the Verkhovna Rada of Ukraine], 2006, No 15, Art.128, [Online], available at:https://zakon.rada.gov.ua/laws/show/3262-15.

${ }^{15}$ The Law of Ukraine(Jul.7, 2010) No. 2453-VI "On the Judiciary and the Status of Judges", Vidomosti Verkhovnoi Rady Ukrainy [The Official Bulletin of the Verkhovna Rada of Ukraine], 2016, No 31, Art. 545, [Online], available at: https://zakon.rada.gov.ua/laws/show/1402-19.

${ }^{16}$ The Law of Ukraine (Jan. 13, 2011) No. 2939-VI "On AccesstoPublicInformation", Vidomosti Verkhovnoi Rady Ukrainy [The Official Bulletin of the Verkhovna Rada of Ukraine], 2011, No 32, Art. 314, [Online], available at: https://zakon.rada.gov.ua/laws/show/2939-17. 
political parties, religious organizations, organizations engaged in professional self-government, etc. According to the Law of Ukraine "On Public Associations"(Article 2, para 3), "Individual aspects of regulation of social relations in the sphere of establishing and registering certain types of public associations in Ukraine, their functioning and termination may be determined by other laws"17.

Along with the legal regulation of public associations' activities at the constitutional and legislative levels, their activities are regulated by the charters of public associations. It is the charter where the purpose (goals) and activities of a public association as well as its interaction with other public organizations, including international ones, are defined. According to Article 9 of the Law of Ukraine "On Public Associations", the presence of the charter and its adoption at the constituent meeting is a premise for the establishment and registration of a public association.

Among the numerous public associations, whose activities are aimed at establishment of the rule of law, human rights protection, the judiciary functioning in Ukraine and, eventually, legal culture improvement, we cannot but mention the following ones: Centre for Democracy and Rule of Law (CEDEM), Centre of Policy and Legal Reform (CPLR), All-Ukrainian Civil Platform New Country, NGO" Public Lustration Committee", All-Ukrainian Public Organization "Ukrainian Bar Association" (UBA), NGO "Centre UA", Centre for Civil Liberties, Crimea SOS, Centre for Economic Strategy, DEJURE Foundation, Ukrainian Centre for European Policy.

It should be noted that among the goals and objectives of their activities, human rights organizations directly determine activities in legal education and legal awareness formation, development of civil society in Ukraine. Thus, the Centre for Democracy and Rule of Law (CEDEM), a think-and-act tank, which has been working in the civil society sector of Ukraine since 2005, is actively engaged in the Civil Society Initiative, which embodies the CEDEM mission in terms of development of the society of active and responsible citizens. Joining efforts, educating citizens and creating communities with responsible and proactive participants are the grounds for positive social transformations. The CEDEM also focuses on financial and institutional support for the Reanimation Package of Reforms, School of Communication (since 2019), where public activists are trained; provision of legal support and consultations for civil society coalitions, strengthening of democratic society in Ukraine; creation of platforms for training, meeting and uniting public

${ }^{17}$ The Law of Ukraine (Mar. 22, 2012) No. 4572-VI “On Public Associations", Vidomosti Verkhovnoi Rady Ukrainy [The Official Bulletin of the Verkhovna Rada of Ukraine], 2013, No 1, Art. 1, [Online], available at: https://zakon.rada.gov.ua/laws/show/4572-17. 
activists for massive projects ${ }^{18}$. Therefore, the CEDEM activities are related to organization and conduction of different legal educational activities which have a direct impact on the legal culture of members of public associations and entities subjected to the impact: social activists, civil servants, subjects of other public associations, the general public.

An important role in the improvement of citizens' legal culture is played by the public organization Centre of Policy and Legal Reform (CPLR). Despite the fact that the CPLR is not a conventional human rights organization, it is the value of human rights that determines its mission and goals. Since the moment of its establishment, the main goal of the CPLR has been development and promotion of implementation of the reform that will be able to ensure democracy and the rule of law in Ukraine, lead our country to EU membership in the future. The CPLR develops and facilitates reforms in Ukraine for strengthening democracy, the rule of law and good governance in the following areas: constitutionalism, governance and public administration, judicial proceedings, criminal justice, combating corruption and civil society development ${ }^{19}$. Taking into account the content and areas of this organization's activities, we can conclude that the main subjects affected are the Ukrainian society as a whole and its active citizens. Within a long time, the Centre has been involved in the elaboration of important draft legal acts on reforms in the judiciary, access to public information, namely participation in the preparation of the draft law "On Access to Court Decisions" adopted by the Parliament in 2005 and currently applied for operation of the Unified State Register of Court Decisions; participation in drafting the Law "On Access to Public Information" developed in 2008 and adopted by the Parliament in 2011 after an extensive campaign by the media and public associations; involvement in the development of the legal reform concept and the draft law "On the Judiciary and the Status of Judges".

In the context of our research, subject the activities of the All-Ukrainian Civil Platform New Country deserve special attention ${ }^{20}$. Among the areas and relevant aspects of its activities there is strategic vision (development of the strategic vision, national idea, strategic vision of cities and regions);reform projects (reform strategy, public communication for reforms, searching and raising funds); reform teams (training of teams for reform implementation, social mobility for civil society activists).Consolidation of civil society (association based on strategic vision, integration of civil society, education, interaction platform for civil society, politicians, authorities, experts) is of great significance. The scope of this organization's activities is provided by

\footnotetext{
${ }^{18}$ Centre for Democracy and Rule of Law (2019), available at: https://cedem.org.ua/.

${ }^{19}$ Centreof Policy and Legal Reform (2019), available at: https://www.pravo.org.ua/ua/about/.

${ }^{20}$ All-Ukrainian Civil Platform New Country(2019), available at: http://novakraina.org/.
} 
cooperation with a number of international associations, in particular the European Endowment for Democracy, Civil Society Dialogue for Progress, UNDP, Konrad Adenauer Stiftung ${ }^{21}$.

It should be noted that cooperation with international NGOs is common for this organization. In Ukraine, a vast majority of public associations' activities aimed at promotion of legal reform, combating corruption, protection of human rights and freedoms, establishment of the rule of law and democracy are more or less related to the activities of international associations, their organizational and material assistance.

Due to the fact that after the Revolution of Dignity there arose the need for authorities cleansing, some public activists, journalists, lawyers, individual MPs, IT-experts initiated the establishment of a nongovernmental organization "Public Lustration Committee", the members of which developed the Law of Ukraine "On Government Cleansing"(Lustration Law),assured its adoption by the Verkhovna Rada of Ukraine and directed their activities towards public control over its implementation. They also initiated a competition to form a Public Lustration Council, the establishment of which is provided for by the Law. Among more than 500 applicants, the list of which was published for open access, the Public Lustration Council under the Ministry of Justice selected twelve persons. Among them, there were investigative journalists, bloggers and social activists $^{22}$. In accordance with the current legislation and general goals, the Committee cooperates with other public associations, namely AutoMaidan, Samooborona, the Open Dialogue Foundation (ODF) from Poland as well as with public authorities, in particular the Lustration Department of the Ministry of Justice of Ukraine, in order to increase the effectiveness of its activities. Among major activities of the Public Lustration Committee, the emphasis is placed on monitoring and analysis, which, in particular, involves screening the officials included in the Uniform Register of persons who are subject to the Law of Ukraine "On Government Cleansing"; informing about the beginning of inspections in various bodies, according to the Inspection Plan approved by the Cabinet of Ministers; tracking trials regarding the reinstatement of officials lustrated; checking officials who remained in office despite the Law requirements; exposing attempts to openly sabotage the Law by officials, recording attempts by officials to avoid lustration by the Public Lustration Council under the Ministry of Justice of Ukraine, which includes authoritative investigative journalists and public activists $^{23}$.

${ }^{21}$ All-Ukrainian Civil Platform New Country(2019), available at: http://novakraina.org/.

22 Public Lustration Committee (2019), available at: https://web.archive.org/web/ 20150601025003/http:/lku.org.ua/.

${ }^{23}$ Public Lustration Committee (2014) The Members of the Public Lustration Council Were Approved, [Online], available at: https://web.archive.org/web/20150501081321/; http:/lku.org.ua/press_articles/148. 
The analysis of the goals and content of the Committee's activities shows that their activities aim to increase the level of legal culture of the general public, statesmen and officials, fundamentally change legal culture and “... keep away from public governance those persons who made decisions, took actions or inaction (and/or contributed to their taking) facilitating power usurpation by the President of Ukraine Viktor Yanukovych and seeking to undermine the foundations of the national security and defence or violate human rights and freedoms. Lustration to be based on the following principles: the rule of law and lawfulness; openness, transparency and public accessibility; presumption of innocence; individual liability; and guarantees of the right to defence" 24 .

Along with public organizations established in recent years in connection with the Revolution of Dignity in Ukraine, which are engaged in legal education activities, organizations established in the early $20^{\text {th }}$ century are still effective and tend to extend their activities. Among them, special attention should be paid to the All-Ukrainian Public Organization "Ukrainian Bar Association"(UBA) ${ }^{25}$, which unites more than 7 thousand lawyers into an influential professional community. Along with the objectives of the legal profession development, introduction of ethical standards, protection of professional rights of UBA members, the areas of legislation improvement and human rights are among the most important ones. The UBA dynamism and activities are based on individual initiative and interest of its members. The UBA maintains relations with the Council of Bars and Law Societies of Europe (CCBE), the American Bar Association (ABA), and is a member of the International Bar Association (IBA) ${ }^{26}$.The analysis of the UBA's goals and activity areas provides grounds to state that to a large extent, its activities are aimed at improving the legal culture of lawyers and the public with active citizenship and legal position.

The limited volume of the present paper makes it impossible to review the content and activities of other public associations engaged in improvement of legal culture, namely NGO "Centre UA", Centre for Civil Liberties, Crimea SOS, Centre for Economic Strategy, DEJURE Foundation, Ukrainian Centre

${ }^{24}$ The Law of Ukraine (Sep. 16, 2014) No. 1682-VII "On Government Cleansing”, Vidomosti Verkhovnoi Rady Ukrainy [The Official Bulletin of the Verkhovna Rada of Ukraine], 2014, No 44, Art. 2041, [Online], available at: https://zakon.rada.gov.ua/laws/show/1682-18.

25 All-Ukrainian Public Organization "Ukrainian Bar Association" (2019), available at: https://uba.ua/ukr/about/(accessed 03 January 2020).

${ }^{26}$ The Law of Ukraine (Sep. 16, 2014) No. 1682-VII "On Government Cleansing", Vidomosti Verkhovnoi Rady Ukrainy [The Official Bulletin of the Verkhovna Rada of Ukraine], 2014, No 44, Art. 2041, [Online], available at: https://zakon.rada.gov.ua/laws/show/1682-18 (in Ukrainian) (accessed 05 January 2020). 
for European Policy, etc. Therefore, in order to identify the areas of influence on legal culture, summarization and systematization of the content and lines of public organizations' activities should be made.

\section{Areas of public organizations' influence on the legal culture of citizens as a basis for the civil society formation in Ukraine}

The need to study the areas of public organizations' influence on the legal culture of citizens as a basis for the civil society formation is due, among other things, to the fact that in recent years, not only has their number increased, but also their role in the Ukrainian society has expanded. The positive experience of public organizations has led to an increase of public confidence in them. According to a survey conducted by the sociological service of the Razumkov Centre from March 21 to 26, 2019, 46\% of respondents trusted public organizations; volunteer organizations were said to be the most trusted ones $(68 \%$ of respondents) ${ }^{27}$. According to a sociological survey conducted by the same Centre from October 4 to 9, 2019, among the state and public institutions, the Armed Forces of Ukraine are most trusted (75\% of respondents trusted them most often), the President of Ukraine (70\%) and volunteer organizations (69\% respectively $)^{28}$. Public trust in public associations has a positive impact on the perception of information they distribute, encourages cooperation, support and dissemination of the values of democracy and the rule of law.

The analysis and systematization of the experience of public organizations, especially of human rights organizations, which have the most significant impact on the legal culture improvement, provides the grounds to identify several main areas and the corresponding measures. Most of the areas and events given below are organized and held by members of public organizations independently or jointly with members of other public associations and the general public. It should be noted that a significant part of them is also held with participation of representatives of state authorities and local self-governments and reflected in the National Strategy for the Support of Civil Society Development in Ukraine for 2016-2020 29 .

${ }^{27}$ Razumkov Centre (2019), The Level of Trust in Public Institutions and Electoral Orientations of Ukrainian Citizens, [Online], available at: http://razumkov.org.ua/napriamky/ sotsiologichnidoslidzhennia/riven-doviry-do-suspilnykh-instytutiv-ta-elektoralni-oriientatsii-gromadian-ukrainy-2.

${ }^{28}$ Rasumkov Centre (2019), Citizens 'assessment of the situation in the country and the activities of the government, the level of trust in social institutions and politicians. The study conducted by the sociological service of the Razumkov Centre from 4 to 9 October 2019, [Online], available at: http://razumkov.org.ua/napriamky/sotsiologichni-doslidzhennia/otsinka-gromadianamy-sytuatsii-vkraini-ta-diialnosti-vlady-riven-doviry-do-sotsialnykh-instytutiv-ta-politykiv.

${ }^{29}$ National Strategy for the Support of Civil Society Development in Ukraine for 2016-2020 (2016). Approved by the President of Ukraine Decree No. 68/2016 of February 26, 2016 "On Support of Civil Society Development in Ukraine", [Online], available at: https://zakon.rada.gov.ua/ laws/show/68/2016\#n20. 
The main areas and activities of public organizations that influence legal culture include the following: 1) participation in consultations with executive authorities, local self-government bodies on draft legal acts; 2) participation in the formation of the procedure for initiating and holding local referendums; 3) organization and conduct of peaceful assemblies; 4) organization of public hearings, development and introduction of local initiatives, implementation of other forms of participatory democracy jointly with state authorities and local self-government bodies; 5) at the level of local authorities, initiation of public consultations, public examination of their activities and activities of their executive bodies and officials, utility companies, organizations and institutions; 6) participation in the mandatory public consultation process of drafting the State budget of Ukraine and local budgets; 7) participation in public examination of the activities in administrative services provision and activities of budgetary institutions providing social services; 8) work on the development of an effective tool for realizing the right of citizens to address local self-government bodies with e-petitions; 9) activities and measures aimed at inclusion of mandatory procedures for ensuring information transparency and openness in the regulations of local councils, including the issues of public involvement in the preparation of draft acts of public importance; 10) organization and implementation of a complex of measures aimed at enhancement of civic education of the population with regard to protection of their rights and articulation of their interests through different forms of participatory democracy; 11) activism and events to increase the application areas for public-private partnerships with participation of civil society associations; 12) activities in legal education aimed at inclusion of courses and topics on the issues of civil society development in the curricula of secondary, vocational and higher schools; 13) carrying out of measures to ensure the provision of methodological, consulting and organizational assistance to public authorities and local self-government bodies on issues of interaction with civil society associations, development of civil society; 14) holding of educational events and social advertising with regard to interaction of civil society institutions and public authorities, local selfgovernment bodies; 15) promotion of scientific research, publications and educational activities in the field of civil society development, protection of human rights and freedoms, promotion of the rule of law and democracy.

The above-mentioned areas and activities include analytical, scientific, consulting, educational, supervisory and organizational work of members of relevant public organizations. In particular, participation in the development of state policy in a certain area of public and legal relations as well as assistance in its proper implementation involves revealing and researching the problems of the state and legal development, analytical forecasting, 
developing concepts of relevant reforms, drafting legal acts, participating in working groups and commissions engaged in the development of draft laws, legal expertise of draft laws, initiating public campaigns, public hearings to support decision-making on certain issues, monitoring implementation of adopted laws, etc. The legal culture subjects being affected in this regard are civil servants, officials, employees of local self-government bodies and all those involved in the development of state policy. The effectiveness of such an impact largely depends on the level of knowledge, competence, professionalism and legal culture of public organizations' members. Therefore, it is extremely important for them to constantly improve their professional and cultural level.

For some public organizations, scientific and consulting activities, which aim to theoretically substantiate proposed changes and convey legal positions to decision-making subjects, is an essential area of work, which is of great significance in influencing the legal culture of both individual categories of citizens and the general public. This activity line involves writing of scientific and practical comments, practical manuals, textbooks, monographs and other scientific publications; translation of outstanding works of Western legal thought representatives with their subsequent publication; translation and publishing of foreign sources of legislation; preparation of expert opinions on requests of ministries, departments and public authorities regarding the decisions they have made. Provision of expert opinions and consultations covers a narrower range of subjects, while writing comments, practical manuals, monographs and articles covers a wider range of subjects. A separate large group consists of students, primarily future lawyers. The opportunity to familiarize themselves with practitioners and legal experts' opinions is quite important for them. In such cases, their legal culture can be transformed in the practical area of the acquired knowledge and skills application.

Educational activities with the view of mobilizing politicians and the public to solve common problems is another important area of public organizations' activity. This work includes holding open lectures, conferences, seminars, trainings (e.g., on issues of judicial process, edocument management at public authorities, etc.), round tables on certain issues, holding press conferences and participating in programmes on relevant topics in the mass media; writing and distributing information booklets and other materials on the mechanisms for asserting their rights in court, in relations with officials, etc. to the general public. In this case, the legal culture subjects being affected are the general public asserting active citizenship and involved in solving public issues.

In recent years, such type of public organizations' activity as monitoring the activities of authorities, the judiciary in particular, has extended 
significantly. State authorities are monitored with regard to observance of the Constitution and laws of Ukraine, obligations arising from the membership in the Council of Europe and conditions of European integration. Preparation and publication of monitoring reports, providing comments to the media with legal assessment of decisions and other events is of importance in such activities.

The above-mentioned areas and measures aimed at improvement of public authorities' efficiency, increase in the role and importance of civil society and improvement of the Ukrainian society's legal culture are not the only activities of public organizations. Special attention should be paid to their activities concerning the influence on the judicial power in Ukraine in the area of adoption of international and European standards of legal proceedings. It is generally recognized that trust in the judiciary lays the foundation for a high level of citizens' legal culture. The areas and forms of public organizations' influence on the judiciary activities in general as well as towards increasing its transparency and accountability in particular, are constantly expanding. At the same time, their influence is determined by the legal principles of transparency and accountability of the judiciary, on the one hand, and autonomy and independence of the judiciary, on the other. For increasing the efficiency of the Ukrainian society's influence on the judiciary towards enhancement of its transparency and accountability, it is extremely important for public organizations' members to have an appropriate level of legal culture, which enables objective assessment of the judiciary, identification of system issues and an effective leverage to increase transparency and accountability of the judiciary to the Ukrainian society.

Another important area of public organizations' influence on the judiciary in the context of increasing its transparency and accountability is scientific and consulting activities with a view of theoretical substantiation of the proposed changes and conveyance of legal positions to decision-making subjects, which consists in holding conferences, seminars, round tables on certain issues; holding press conferences, participating in programmes on relevant topics in the mass media; conducting trainings on specific issues of an applied nature (e.g., establishment and operation of centres on issues of the judicial process, electronic legal proceedings, etc.); writing and distributing brochures and other materials on the mechanisms for asserting their rights in court; writing scientific and practical comments, practical manuals, textbooks, monographs and other scientific publications; facilitating the translation and publication of outstanding works of the Western legal thought as well as of foreign sources of legislation; conveyance of legal positions on requests of judges of the Constitutional Court of Ukraine; preparation of expert opinions on requests of ministries and other public authorities regarding the decisions they have made. Along with the 
relevant knowledge, this type of legal education work requires their organizers to have organizational and communication skills as well as unity of their active citizen's stand and legal position.

In recent years, the most significant areas and measures of public organizations' influence on the judiciary, which have drastically affected the legal culture of the Ukrainian society, have been the following: participation of public organizations in creating the legal basis for introduction of private performers; advocating the establishment of the High Anti-Corruption Court of Ukraine; participation in the activities of the Public Integrity Council with regard to assessment of candidates to the new Supreme Court; participation in interviews with candidates to the High Qualification Commission of Judges of Ukraine and making conclusions about their good/bad faith; organization and conduct of a series of regional trainings on the issues of public influence on judicial reform; participation in analytical studies (in particular, the impact of the armed conflict on justice).

At this level, it is extremely important that legal culture of the subjects of influence (public organizations' members) should be at the highest level; they should have a sufficiently high level of knowledge and critical legal thinking. Their communication culture is also of importance, which, among other things, provides for the ability to conduct a discussion, justify their own position and consider critical comments of colleagues as well as for legal competence. Legal competence is not only the result of training, but also a performance characteristic of the subject's ability to perform legal activities, which is formed on the basis of the use of relevant knowledge, skills, experience, its existing values and stand in life. Legal competence is based on the fact that the law becomes a value, adherence to the norms is an internal belief of the individual, which allows him to objectively assess and solve the problems that arise in various spheres of public relations. As an integrated result of legal knowledge acquisition, it enables a person to holistically implement legal knowledge, relevant skills and values in practice, contains cognitive, value-motivational and practical-behavioral components, and is of an objective-subjective nature.

Public supervision and activity of public assessors are among the forms of public organizations' influence on judicial authorities. In this context, a striking example is establishment of the Institute of Public Assessors by the NGO Anti-Corruption Council within the framework of the Fair Trial project $^{30}$. The main objective of the Fair Trial project is supervision of the judiciary, protection of the ordinary citizen's rights in court against violations by the judiciary, court staff (court clerks, court administrators) and other trial

\footnotetext{
${ }^{30}$ Fair Trial (2020), available at: http://akrsud.kharkiv.ua/.
} 
participants (prosecutors, representatives of other state institutions). Public assessors use various methods in their work, namely: 1) requests to the judge and assistant judges in case of violations; 2) video recording of the trial; 3 ) analysis of court hearing conduct and judges' actions; 4) response to illegal actions and inaction of the judicial authorities; 5) assessment of individual judges' performance; 6) conclusions about fairness of sentences, decisions, rulings and definitions. At the same time, all observations and conclusions are covered on the website and in the Ukrainian media ${ }^{31}$.

Such activity of public assessors also requires a high legal culture, legal knowledge, skills, constant analysis of the current legislation, tracing changes related to the judiciary activities. Effective and high-quality performance of public assessors provides for the fact that they have a professional legal thinking of lawyer, which is characterized by certainty (an ability to determine a problem situation), efficiency, dynamism (an ability to navigate the situation), consistency, criticism, objectivity, depth and breadth, flexibility, etc. In this sense, the activity of public assessors is quite close to that of judicial observers in trial monitoring.

Global experience in the judiciary performance improvement shows that an effective and powerful tool for supporting judicial reform in many civilized democratic countries is trial monitoring, which has been widely recognized over the past decade". The participating States of the Organization for Security and Co-operation in Europe (OSCE) have agreed to accept as a confidence-building measure the presence of observers from other OSCE participating States and non-governmental organizations (NGOs) at proceedings before their courts. By systematic gathering of reliable information on trial conduct, these programmes aim to help States develop effective justice systems which ensure adjudication of cases in accordance with the rule of law and international fair trial standards" ${ }^{\prime 3}$. Among the main forms used in this area, we should highlight the training of almost 100 trial observers (in the spring and summer of 2017, 24 of them, together with 5 experts of the Centre of Policy and Legal Reform (CPLR), monitored 1,400 court sessions. The monitoring results are provided in the report ${ }^{33}$.

Observers' training, which combined trainings and quests in Kiev courts, was a positive experience aimed at improvement of their legal culture.

${ }^{31}$ Fair Trial (2020), available at: http://akrsud.kharkiv.ua/.

32 OSCE Office for Democratic Institutions and Human Rights (2015) Trial Monitoring. A Reference Manual for Practitioners. Retrieved from: https://www.osce.org/odihr/94216? download=true.

${ }^{33}$ Centre of Policy and Legal Reform (2018) Presentation report on the results of the trial monitoring programme in Ukraine. [Online], available at: https://pravo.org.ua/ua/news/ 20872698-prezentatsiyniy-zvit-za-rezultatami-programi-monitoringu-sudovih-protsesiv-v-ukrayini. 
Without such training and improvement of the general level of trial observers' legal culture, the quality and effectiveness of their performance would be incorrect. Therefore, the practice of conducting trainings for the public, whose activities are aimed at increasing the transparency and accountability of the judiciary to the Ukrainian society, requires to be further extended.

It should be noted that despite the absence of a long tradition of civil society institutions' influence on the judicial authorities in Ukraine, there are certain positive changes in the area of increasing transparency and accountability of the judiciary to the Ukrainian society, in particular creation of the e-database of the Supreme Court positions with a convenient search system and a newly-introduced well-structured form of judicial decision, clearer and more accessible. A special role is played by the introduction of online broadcasts of all open court sessions and full communication with the parties via the Internet (e-court). Thus, in the Ukraine Judiciary Development Strategy 2015-2019, e-justice is recognized as a strategic issue that contributes to access to justice and trial improvement ${ }^{34}$. Information technologies in legal proceedings are a key tool for improving access to justice, improving the efficiency of courts and increasing their transparency. Therefore, it is necessary to make significant efforts to introduce e-justice, improve it and strengthen the interaction between these information systems and those of other justice bodies. This will help to increase transparency and accountability of the judiciary to the public in Ukraine. A more intensive use of e-justice will enable citizens and civil society institutions to track and record trials as well as receive all relevant documentation by electronic means.

We should note that the above discussed areas and measures of public organizations' influence on legal culture are much wider. Thus, Rabadi Bsher Saddam Nabeel quite rightly focuses on the role of public organizations in supporting foreign students with formation of their legal culture, in particular, with regard to the issues of education and residence in Ukraine ${ }^{35}$. The legal basis for interaction between international and Ukrainian public associations, influence of international NGOs on the legal culture of the Ukrainian society and development of civil society in Ukraine, problems of improving the legal culture of certain categories and groups, in particular young people, displaced

${ }^{34}$ Ukraine Judiciary Development Strategy 2015-2019. Retrieved from: https://court.gov.ua/ userfiles/strategij.pdf.

${ }^{35}$ Rabad i (Bsher Saddam) Nabeel (2019) Rol hromadskykh orhanizatsii u formuvanni pravovoi kultury suspilstva [The role of public organizations in shaping the legal culture of society].Retrieved from: file:///C:/Users/\%D0\%90\%D0\%B4\%D0\%BC\%D0\%B8\%D0\%BD\% D0\%B8\%D1\%81\%D1\%82\%D1\%80\%D0\%B0\%D1\%82\%D0\%BE\%D1\%80/Downloads/781127536-1-PB.pdf. 
persons, forced migrants and foreigners, who reside in Ukraine may become the subject of separate studies in the context of public organizations.

\section{CONCLUSIONS}

The analysis made in our paper provides the grounds for making a number of conclusions and generalizations. The areas of public organizations' influence on legal culture as a basis for civil society formation are determined by the theoretical and legal premises for their activities. At the international level, there is a strong legal framework that regulates the right to freedom of association and provides the basis for the national law and legislation with the view of recognizing the right to association as an integral part of a democratic society. The analysis of the current legislation shows that the legal basis of public organizations' activities, their influence on civil society and legal culture are provided for by the Constitution of Ukraine (in particular, Articles 36, 37, 40), the Laws of Ukraine "On Public Associations", "On Access to Public Information", "On Access to Court Decisions", "On the Judiciary and the Status of Judges", etc.

Among the numerous public organizations, the activities of which are aimed at establishing the rule of law, protecting human rights, functioning of the judiciary in Ukraine, and eventually improving legal culture, we should single out human rights organizations. The main areas and activities of public organizations that influence legal culture include the following: organizing and conducting peaceful assemblies; organizing public hearings jointly with state authorities, developing and introducing local initiatives as well as implementing other forms of participatory democracy; participating in public examination of activities in provision of administrative services; organizing and carrying out complex measures aimed at improving civil legal awareness of the population concerning their rights and interests' protection through different forms of participatory democracy; performing legal education activities, etc. Special attention should be paid to the activities of public organizations in influencing the judiciary in Ukraine towards the adoption of the international and European standards of justice and improvement of citizens' legal culture with regard to judiciary functioning. One of the forms of public organizations' influence on the judicial authorities is public supervision and activity of public assessors. The above-mentioned areas and measures of public organizations' influence on legal culture are much wider. The legal basis for interaction between international and Ukrainian public organizations, international NGOs' influence on the legal culture of the Ukrainian society and civil society development in Ukraine, problems of improving the legal culture of certain categories and groups, in particular young people, displaced persons, forced migrants and foreigners, who reside 
in Ukraine, may become the subject of separate studies in the context of public organizations.

\section{SUMMARY}

The experience of social development of modern democratic countries clearly shows that the level of civilizational development in general and that of political, legal, and cultural development in particular, depend significantly on the functioning of civil society, which contributes to settlement of social conflicts by legal means. Public organizations play an important role among the many subjects of civil society.

The areas of public organizations' influence on legal culture as a basis for civil society formation are determined by the theoretical and legal premises for their activities. At the international level, there is a strong legal framework that regulates the right to freedom of association and provides the basis for the national law and legislation with the view of recognizing the right to association as an integral part of a democratic society.

The analysis of the current legislation shows that the legal basis of public organizations' activities, their influence on civil society and legal culture are provided for by the Constitution of Ukraine (in particular, Articles 36, 37, 40), the Laws of Ukraine "On Public Associations", "On Access to Public Information", "On Access to Court Decisions", "On the Judiciary and the Status of Judges", etc.

Among the numerous public organizations, the activities of which are aimed at establishing the rule of law, protecting human rights, functioning of the judiciary in Ukraine, and eventually improving legal culture, we should single out human rights organizations. The main areas and activities of public organizations that influence legal culture include the following: organization of public hearings, development and introduction of local initiatives, implementation of other forms of participatory democracy jointly with state authorities and local self-government bodies; at the level of local authorities, initiation of public consultations, public examination of their activities and activities of their executive bodies and officials, utility companies, organizations and institutions; organization and implementation of a complex of measures aimed at enhancement of civic education of the population with regard to protection of their rights and articulation of their interests through different forms of participatory democracy; activities in legal education, etc. Special attention should be paid to public organizations' activities in influencing the judiciary in Ukraine towards the adoption of the international and European standards of justice and improvement of citizens' legal culture with regard to judiciary functioning. One of the forms of public organizations' influence on the judicial authorities is public supervision and activity of public 
assessors. The above-mentioned areas and measures of public organizations' influence on legal culture are much wider. The legal basis for interaction between international and Ukrainian public associations, international NGOs' influence on the legal culture of the Ukrainian society and civil society development in Ukraine, problems of improving the legal culture of certain categories and groups, in particular young people, displaced persons, forced migrants and foreigners, who reside in Ukraine, may become the subject of separate studies in the context of public organizations.

\section{REFERENCES}

1. National Strategy for the Support of Civil Society Development in Ukraine for 2016-2020 (2016). Approved by the President of Ukraine Decree No. 68/2016 of February 26, 2016 "On Support of Civil Society Development in Ukraine", [Online], available at: https://zakon.rada.gov.ua/laws/show/ 68/2016\#n20(in Ukrainian) (accessed 10 January 2020).

2. UN General Assembly. International Covenant on Civil and Political Rights (December 16, 1966), United Nations. Treaty Series, vol. 999, p. 171, Article 22, [Online], available at: https://www.ohchr.org/en/professional interest/pages/ccpr.aspx (accessed 02 January 2020).

3. Council of Europe. European Convention for the Protection of Human Rights and Fundamental Freedoms, as amended by Protocols Nos. 11 and 14, 4 November 1950, Article 11, [Online], available at: http://conventions.coe.int/treaty/Commun/QueVoulezVous.asp?NT=005\&CL= ENG (accessed 22 June 2019).

4. UN General Assembly. International Covenant on Economic, Social and Cultural Rights (December 16, 1966), United Nations, Treaty Series, vol. 993, p. 3, Article 8.Retrieved from: https://www.ohchr.org/Documents/ ProfessionalInterest/cescr.pdf (accessed 02 January 2020).

5. European Union. Charter of Fundamental Rights of the European Union (October 26, 2012), 2012/C 326/02,Official Journal of the European Union,Article 12,[Online], available at: https://eur-lex.europa.eu/legalcontent/EN/TXT/?uri=uriserv:OJ.C_.2012.326.01.0391.01.ENG\&toc=OJ:C:2 012:326:TOC (accessed 05 January 2020).

6. The OSCE Office for Democratic Institutions and Human Rights (2015) Guidelines on Freedom of Association, p. 15. Retrieved from: https://www.osce.org/odihr/132371?download=true (accessed 15 December 2019).

7. The Constitution of Ukraine (June 28, 1996), Vidomosti Verkhovnoi Rady Ukrainy [The Official Bulletin of the Verkhovna Rada of Ukraine], 1996, No 30, Art. 141 (as amended by the Law of Ukraine "On Amendments to the Constitution of Ukraine (concerning justice)"(June 2, 2016), Vidomosti 
Verkhovnoi Rady Ukrainy [The Official Bulletin of the Verkhovna Rada of Ukraine], 2016, No 51, p. 8, Art. 1799), [Online], available at: https://zakon.rada.gov.ua/laws/main/254\%D0\%BA/96-\%D0\%B2\%D1\%80 (in Ukrainian) (accessed 03 January 2020).

8. The Constitution of Ukraine (June 28, 1996), Vidomosti Verkhovnoi Rady Ukrainy [The Official Bulletin of the Verkhovna Rada of Ukraine], 1996, No 30, Art. 141 (as amended by the Law of Ukraine "On Amendments to the Constitution of Ukraine (concerning justice)"(June 2, 2016), Vidomosti Verkhovnoi Rady Ukrainy [The Official Bulletin of the Verkhovna Rada of Ukraine], 2016, No 51, p. 8, Art. 1799), [Online], available at: https://zakon.rada.gov.ua/laws/main/254\%D0\%BA/96-\%D0\%B2\%D1\%80 (in Ukrainian) (accessed 03 January 2020).

9. The Constitution of Ukraine (June 28, 1996), Vidomosti Verkhovnoi Rady Ukrainy [The Official Bulletin of the Verkhovna Rada of Ukraine], 1996, No 30, Art. 141 (as amended by the Law of Ukraine "On Amendments to the Constitution of Ukraine (concerning justice)" (June 2, 2016), Vidomosti Verkhovnoi Rady Ukrainy [The Official Bulletin of the Verkhovna Rada of Ukraine], 2016, No 51, p. 8, Art. 1799), [Online], available at: https://zakon.rada.gov.ua/laws/main/254\%D0\%BA/96-\%D0\%B2\%D1\%80 (in Ukrainian) (accessed 03 January 2020).

10. The Law of Ukraine (Mar. 22, 2012) No. 4572-VI "On Public Associations", Vidomosti Verkhovnoi Rady Ukrainy [The Official Bulletin of the Verkhovna Rada of Ukraine], 2013, No 1, Art. 1, [Online], available at:https://zakon.rada.gov.ua/laws/show/4572-17 (in Ukrainian) (accessed 03 January 2020).

11. The Law of Ukraine (Mar. 22, 2012) No. 4572-VI "On Public Associations", Vidomosti Verkhovnoi Rady Ukrainy [The Official Bulletin of the Verkhovna Rada of Ukraine], 2013, No 1, Art. 1, [Online], available at: https://zakon.rada.gov.ua/laws/show/4572-17 (in Ukrainian) (accessed 03 January 2020).

12. The Law of Ukraine (Mar. 22, 2012) No. 4572-VI "On Public Associations", Vidomosti Verkhovnoi Rady Ukrainy [The Official Bulletin of the Verkhovna Rada of Ukraine], 2013, No 1, Art. 1, [Online], available at: https://zakon.rada.gov.ua/laws/show/4572-17 (in Ukrainian) (accessed 03 January 2020).

13. The Law of Ukraine (Jan. 13, 2011) No. 2939-VI "On Access to Public Information", Vidomosti Verkhovnoi Rady Ukrainy [The Official Bulletin of the Verkhovna Rada of Ukraine], 2011, No 32, Art. 314, [Online], available at: https://zakon.rada.gov.ua/laws/show/2939-17 (in Ukrainian) (accessed 03 January 2020). 
14. The Law of Ukraine (Dec. 22, 2005) No. 3262-IV “On Access to Court Decisions", Vidomosti Verkhovnoi Rady Ukrainy [The Official Bulletin of the Verkhovna Rada of Ukraine], 2006, No 15, Art. 128, [Online], available at: https://zakon.rada.gov.ua/laws/show/3262-15 (in Ukrainian) (accessed 03 January 2020).

15. The Law of Ukraine (Jul.7, 2010) No. 2453-VI "On the Judiciary and the Status of Judges", Vidomosti Verkhovnoi Rady Ukrainy [The Official Bulletin of the Verkhovna Rada of Ukraine], 2016, No 31, Art. 545, [Online], available at: https://zakon.rada.gov.ua/laws/show/1402-19 (in Ukrainian) (accessed 03 January 2020).

16. The Law of Ukraine (Jan. 13, 2011) No. 2939-VI "On Access to Public Information", Vidomosti Verkhovnoi Rady Ukrainy [The Official Bulletin of the Verkhovna Rada of Ukraine], 2011, No 32, Art. 314, [Online], available at: https://zakon.rada.gov.ua/laws/show/2939-17 (in Ukrainian) (accessed 03 January 2020).

17. The Law of Ukraine (Mar. 22, 2012) No. 4572-VI "On Public Associations", Vidomosti Verkhovnoi Rady Ukrainy [The Official Bulletin of the Verkhovna Rada of Ukraine], 2013, No 1, Art. 1, [Online], available at: https://zakon.rada.gov.ua/laws/show/4572-17 (in Ukrainian) (accessed 03 January 2020).

18. Centre for Democracy and Rule of Law (2019), available at: https://cedem.org.ua/(accessed 23 December 2019).

19. Centre of Policy and Legal Reform (2019), available at: https://www.pravo.org.ua/ua/about/(accessed 23 December 2019).

20. All-Ukrainian Civil Platform New Country (2019), available at: http://novakraina.org/(accessed 23 December 2019).

21. All-Ukrainian Civil Platform New Country (2019), available at: http://novakraina.org/(accessed 23 December 2019).

22. Public Lustration Committee (2019), available at: https://web.archive.org/web/20150601025003/http:/lku.org.ua/ (accessed 23 December 2019).

23. Public Lustration Committee (2014)The Members of the Public Lustration Council Were Approved, [Online], available at: https://web.archive.org/web/20150501081321/http:/lku.org.ua/press_articles/1 48 (in Ukrainian) (accessed 03 January 2020).

24. The Law of Ukraine (Sep. 16, 2014) No. 1682-VII "On Government Cleansing “, Vidomosti Verkhovnoi Rady Ukrainy [The Official Bulletin of the Verkhovna Rada of Ukraine], 2014, No 44, Art. 2041, [Online], available at: https://zakon.rada.gov.ua/laws/show/1682-18 (in Ukrainian) (accessed 05 January 2020). 
25. All-Ukrainian Public Organization “Ukrainian Bar Association”(2019), available at: https://uba.ua/ukr/about/(accessed 03 January 2020).

26. The Law of Ukraine (Sep. 16, 2014) No. 1682-VII "On Government Cleansing “, Vidomosti Verkhovnoi Rady Ukrainy [The Official Bulletin of the Verkhovna Rada of Ukraine], 2014, No 44, Art. 2041, [Online], available at: https://zakon.rada.gov.ua/laws/show/1682-18 (in Ukrainian) (accessed 05 January 2020).

27. Rasumkov Centre (2019), The Level of Trust in Public Institutions and Electoral Orientations of Ukrainian Citizens, [Online], available at: http://razumkov.org.ua/napriamky/sotsiologichni-doslidzhennia/riven-dovirydo-suspilnykh-instytutiv-ta-elektoralni-oriientatsii-gromadian-ukrainy-2(in Ukrainian) (accessed 05 January 2020).

28. Rasumkov Centre (2019), Citizens 'assessment of the situation in the country and the activities of the government, the level of trust in social institutions and politicians. The study conducted by the sociological service of the Razumkov Centre from 4 to 9 October 2019, [Online], available at: http://razumkov.org.ua/ napriamky/sotsiologichni-doslidzhennia/otsinka-gromadianamy-sytuatsii-v-krainita-diialnosti-vlady-riven-doviry-do-sotsialnykh-instytutiv-ta-politykiv

(in Ukrainian) (accessed 05 January 2020).

29. National Strategy for the Support of Civil Society Development in Ukraine for 2016-2020 (2016). Approved by the President of Ukraine Decree No. 68/2016 of February 26, 2016 "On Support of Civil Society Development in Ukraine", [Online], available at: https://zakon.rada.gov.ua/laws/ show/68/2016\#n20(in Ukrainian) (accessed 10 January 2020).

30. Fair Trial (2020), available at: http://akrsud.kharkiv.ua/ (accessed 12 January 2020).

31. Fair Trial (2020), available at: http://akrsud.kharkiv.ua/ (accessed 12 January 2020).

32. OSCE Office for Democratic Institutions and Human Rights (2015) Trial Monitoring. A Reference Manual for Practitioners. Retrieved from: https://www.osce.org/odihr/94216?download=true (accessed 12 January 2020).

33. Centre of Policy and Legal Reform (2018) Presentation report on the results of the trial monitoring programme in Ukraine. [Online], available at: https://pravo.org.ua/ua/news/20872698-prezentatsiyniy-zvit-za-rezultatamiprogrami-monitoringu-sudovih-protsesiv-v-ukrayini(in Ukrainian) (accessed 10 January 2020).

34. Ukraine Judiciary Development Strategy 2015-2019. Retrieved from: https://court.gov.ua/userfiles/strategij.pdf(in Ukrainian) (accessed 14 January 2020). 
35. Rabadi (Bsher Saddam) Nabeel (2019) Rol hromadskykh orhanizatsii u formuvanni pravovoi kultury suspilstva [The role of public organizations in shaping the legal culture of society]. Retrieved from: file://C:/Users/ \%D0\%90\%D0\%B4\%D0\%BC\%D0\%B8\%D0\%BD\%D0\%B8\%D1\%81\%D1\% 82\%D1\%80\%D0\%B0\%D1\%82\%D0\%BE\%D1\%80/Downloads/7811-275361-PB.pdf. (in Ukrainian) (accessed 14 January 2020).

\section{Information about the author:}

Larysa Udovyka, Dr. hab. in Law, Professor, Head of the Department of the Law Faculty, Zaporizhzhia National University 10/8, Verkhnia str., Zaporizhzhia, 69032, Ukraine ORCID ID: orcid.org/0000-0001-9260-4474 